\title{
LAMA PENGUNAAN KONTRASEPSI PIL DAN SUNTIK PADA WANITA PASANGAN USIA SUBUR DENGAN KEJADIAN HIPERTENSI
}

\section{(The Duration Of Use Pil And Injection Contraception On Productive Women Age With Hypertension)}

\author{
Immawanti ${ }^{1}$, Junaedi Yunding ${ }^{2}$ \\ ${ }^{1)}$ STIKes Marendeng Majene, Jln. R.A. Kartini Majene \\ ${ }^{2)}$ Universitas Sulawesi Barat, Jl. Sultan Hasanuddin Majene \\ E-mail: immawanti.ch@gmail.com,
}

\begin{abstract}
ABSTRAK
Penggunaan metode kontrasepsi hormonal dalam waktu lama dapat menimbulkan efek samping salah satunya adalah peningkatan tekanan darah atau hipertensi. Tujuan penelitian ini untuk mengetahui hubungan lama penggunaan kontrasepsi hormonal jenis pil dan suntik pada wanita pasangan usia subur dengan kejadian hipertensi. Rancangan penelitian ini merupakan survey analitik dengan pendekatan cross sectional study. Sampel sebanyak 67 wanita pasangan usia subur, sampel diperoleh dengan menggunakan teknik simple random sampling. Alat ukur yang digunakan adalah spignomanometer dan lembar kuisioner. Hasil penelitian ini menunjukan ada hubungan lama penggunaan kontrasepsi hormonal pil $(p=0,00)$ dan kontrasepsi hormonal suntik $(p=0,01)$ dengan kejadian hipertensi pada wanita pasangan usia subur. Diharapkan instansi terkait untuk memberikan informasi tentang kelebihan dan kelemahan penggunaan jenis kontrasepsi bagi calon akseptor.
\end{abstract}

Kata Kunci : hipertensi, kontrasepsi pil, kontrasepsi suntik, lama pemakaian

\begin{abstract}
ABSTRAC
The use of hormonal contraceptive methods for a long time can cause side effects one of them is an increase in blood pressure or hypertension. The purpose of this study to determine the relationship between the use of contraceptive hormonal type pill and injection in women couples of childbearing age with the incidence of hypertension. The design of this study is an analytical survey with cross sectional study approach. A sample of 67 female couples of childbearing age, the sample was obtained by using simple random sampling technique. The measuring instrument used is spignomanometer and questionnaire sheet. The results of this study showed a long association of hormonal contraceptive use $(p=0,00)$ and injectable hormonal contraception $(p=0.01)$ with hypertension occurrence in women of fertile couples. It is expected that the relevant agencies to provide information about the advantages and disadvantages of using contraceptive types for prospective acceptors.
\end{abstract}

Keyword : Hypertension, Pill Contraceptives, Injectable Contraception, Duration of Use

\section{PENDAHULUAN}

Indonesia merupakan negara dengan jumlah penduduk terbesar keempat di dunia, setelah Cina, India dan Amerika. Besarnya jumlah penduduk ini terkait dengan tingginya angka pertumbuhan penduduk Indonesia dimasa lalu yang dipengaruhi oleh tingkat kelahiran (Tukiman, 2012). Untuk menekan jumlah kelahiran tersebut, saat ini pemerintah telah menerapkan program Keluarga
Berencana bagi wanita Pasangan Usia Subur (PUS) untuk menggunakan alat kontrasepsi.

Ada beberapa metode kontrasepsi yang dapat digunakan meliputi non hormonal seperti kondom, AKDR (Alat Kontrasepsi Dalam Rahim - IUD) dan alat kontrasepsi hormonal antara lain Pil KB, suntik KB, Implant serta metode kontrasepsi mantap yaitu tubektomi dan vasektomi (Saifuddin, 2005). Penggunaan kontrasepsi hormonal 
dalam waktu lama dapat menimbulkan efek samping salah satunya adalah peningkatan tekanan darah atau disebut dengan hipertensi. Hipertensi ini disebabkan karena terjadinya hipertropi jantung dan peningkatan respon pressor angiotensin II dengan melibatkan jalur Renin Angiotensin System (Pangaribuan, 2013).

Berdasarkan data World Health Organization (WHO), pada negara maju, sekitar 330 juta orang yang mengalami hipertensi dan sekitar 640 juta orang pada negara berkembang. Prevalensi hipertensi di Indonesia berdasarkan jenis kelamin tahun 2013 didapatkan bahwa jumlah penderita hipertensi laki-laki sebesar $22.8 \%$ dan perempuan sebesar 28.8\%. (Riskesdas; Infodatin hipertensi, 2013). Provinsi Sulawesi Barat yang memiliki prevalensi tertinggi adalah Kabupaten Majene 23,74\%, dan terendah adalah Kabupaten Mamuju Utara sebesar 15,87\%. Kabupaten Mamuju prevalensi hipertensi sebesar $22,72 \%$ atau menempati urutan ketiga setelah Majene dan Mamasa. (Dinkes, 2014). Data awal yang didapatkan diwilayah kerja Puskesmas Tommo, didapatkan jumlah penderita hipertensi pada periode Januari-Mei 2016 sebanyak 307 kasus hipertensi secara keseluruhan. Observasi awal yang dilakukan oleh peneliti dari 10 pasangan usia subur yang menjadi akseptor KB pil dan suntik, empat diantaranya menderita hipertensi. Hipertensi disebabkan oleh berbagai faktor, salah satunya adalah penggunaan kontrasepsi hormonal (Hartanto, 2010).

Hal ini sejalan dengan penelitian oleh Lestari (2013), bahwa ada hubungan penggunaan kontrasepsi hormonal dengan kejadian hipertensi. Pada penelitian ini pula didapatkan ibu yang lama menggunakan metode kontrasepsi hormonal 3 kali lipat beresiko terkena hipertensi. Penelitian lain oleh Kaunang (2014) diperoleh hasil bahwa ada hubungan antara lama penggunaan kontrasepsi hormonal dengan kejadian hipertensi. Oleh karena masih banyaknya penderita hipertensi di Kabupaten Mamuju khususnya di Desa Tommo II, sehingga peneliti merasa penting kiranya dilakukan suatu penelitian mengenai hubungan lama penggunaan kontrasepsi hormonal pil dan suntik pada wanita pasangan usia subur dengan kejadian hipertensi di Desa Tommo II Kabupaten Mamuju.

\section{METODE}

Desain penelitian ini adalah survey analitik dengan pendekatan cross sectional study. Populasi dalam penelitian ini adalah semua wanita Pasangan Usia Subur (PUS) yang menjadi akseptor KB hormonal. Jumlah sampel sebanyak 67 responden. Sampel diambil dengan cara simple random sampling.

Penelitian ini menggunakan kuisioner meliputi data demografi responden, alat kontrasepsi yang digunakan serta lama responden menggunakan alat kontrasepsi. Sedangkan untuk mengetahui kejadian hipertensi peneliti menggunakan alat ukur yaitu sphygmomanometer dan stetoskop.

Prosedur penelitian ini yaitu peneliti terlebih dahulu menjelaskan tentang maksud dan tujuan penelitian, setelah responden memahami penjelasan tersebut maka responden diminta kesediaanya untuk menandatangani lembar informed consent. Jika responden bersedia, maka peneliti memulai wawancara. Setelah wawancara selesai, peneliti melakukan pengukuran tekanan darah responden. Untuk pengukuran tekanan darah, peneliti melibatkan asisten peneliti untuk membantu dalam melakukan pengukuran tekanan darah. Selanjutnya data dikumpulkan untuk diolah dan dianalisis. Pengolahan data yaitu dengan cara Editing, Coding, Enrty, Tabulasi. Analisis data menggunakan analisis univariat dan analisis bivariat. Etika dalam penelitian ini yaitu Informed Consent, Anonimity, Comfidentiality.

\section{HASIL}

Tabel 1.Lama penggunaan kontrasepsi hormonal pil pada wanita pasangan usia subur dengan kejadian hipertensi

\begin{tabular}{|c|c|c|c|c|c|c|c|}
\hline \multicolumn{7}{|c|}{ Tekanan Darah } & \multirow{3}{*}{$P$} \\
\hline \multirow{2}{*}{$\begin{array}{c}\text { Lama } \\
\text { Pemakaian } \\
\text { Pil }\end{array}$} & \multicolumn{2}{|c|}{ Hipertensi } & \multicolumn{2}{|c|}{$\begin{array}{c}\text { Tidak } \\
\text { Hipertensi }\end{array}$} & \multicolumn{2}{|c|}{ Jumlah } & \\
\hline & $\mathbf{n}$ & $\%$ & $\mathbf{n}$ & $\%$ & $\mathbf{n}$ & $\%$ & \\
\hline Lama & 24 & 72.7 & 2 & 6.1 & 26 & 78.8 & Q \\
\hline Baru & 0 & 0.0 & 7 & 21.2 & 7 & 21.2 & 0.00 \\
\hline Jumlah & 24 & 72.7 & 9 & 27.3 & 33 & 100 & \\
\hline
\end{tabular}


Terdapat hubungan yang bermakna antara lama penggunaan kontrasepsi hormonal pil pada wanita pasangan usia subur dengan kejadian hipertensi dengan nilai $p=0,00$.

Tabel 2. Lama penggunaan kontrasepsi hormonal suntik pada wanita pasangan usia subur dengan kejadian hipertensi

respon presor angiotensin II dengan melibatkan jalur Renin Angiotensin System.

Pengaruh pil KB pada sistem tubuh salah satunya pada sistem pembekuan darah. Estrogen akan meningkatkan aktivitas pembekuan darah, sehingg akan memudahkan trombosit (pembekuan) di pembuluh darah, akibat lanjut menyebabkan sumbatan dan gangguan pada aliran darah. Makin besar dosis estrogen yang diberikan,

\begin{tabular}{|c|c|c|c|c|c|c|c|}
\hline \multicolumn{7}{|c|}{ Tekanan Darah } & Makin besar dosis estrogen yang diberil \\
\hline \multirow{2}{*}{$\begin{array}{c}\text { Lama } \\
\text { Pemakaian } \\
\text { Suntik }\end{array}$} & \multicolumn{2}{|c|}{ Hipertensi } & \multicolumn{2}{|c|}{$\begin{array}{l}\text { Tidak } \\
\text { Hipertensi }\end{array}$} & \multicolumn{2}{|c|}{ Jumlah } & $\begin{array}{l}\text { makin besar pula efeknya. Begitu pula e } \\
\boldsymbol{P} \text { yang ditimbulkan pada sistem kardiovask }\end{array}$ \\
\hline & $\mathbf{n}$ & $\%$ & $\mathbf{n}$ & $\%$ & $\mathbf{n}$ & $\%$ & serebrovaskuler. Pemakaian pil \\
\hline Lama & 13 & 38.2 & 7 & 20.6 & 20 & 58.8 & tromboemholi \\
\hline Baru & 2 & 5.9 & 12 & 35.3 & 14 & 41.2 & 01 \\
\hline Jumlah & 15 & 44.1 & 19 & 55.9 & 33 & 100 & \\
\hline
\end{tabular}

Terdapat hubungan yang bermakna antara lama penggunaan kontrasepsi hormonal suntik pada wanita pasangan usia subur dengan kejadian hipertensi dengan nilai $p=0,01$.

\section{PEMBAHASAN}

Sebanyak 33 responden yang menggunakan kontrasepsi pil dengan kategori lama sebanyak 24 orang $(72,7 \%)$ responden yang menderita hipertensi dan responden yang tidak menderita hipertensi sebanyak 2 orang $(6,1 \%)$, sedangkan responden yang memakai alat kontrasepsi pil dengan kategori baru didapatkan sebanyak 7 orang $(21,2 \%)$ tidak menderita hipertensi.

Hasil penelitian ini sejalan dengan penelitian oleh Sumiati (2016), yang menyatakan bahwa dari 65 responden yang memakai alat kontrasepsi pil sebanyak 39 orang atau $60 \%$ yang menggunakan kontrasepsi lebih dari 2 tahun menderita hipertensi.

Menurut Hartanto (2010), menjelaskan bahwa tekanan darah sama atau lebih dari $140 / 90 \mathrm{mmHg}$, ini disebabkan karena kasiat estrogen terhadap pembuluh darah sehingga terjadi hipertropi arteriola dan vasokontriksi. Penggunaan kontrasepsi pil dalam waktu lama dapat menimbulkan efek samping salah satunya adalah peningkatan tekanan darah (hipertensi). Hal ini terjadi karena hipertropi jantung dan peningkatan
Tromboemboli terjadi akibat perubahan system pembekuan darah akibat estrogen, disamping efek arteriosklerosis oleh pengaruh progesterone. Resiko akan meningkat pada perokok, penderita penyakit diabetes mellitus, riwayat obesitas, diet garam yang berlebihan dan lain-lain. Hipertensi dapat terjadi pada 5\% pemakai pil $\mathrm{KB}$, hal ini dipengaruhi usia, jenis kelamin, suku dan riwayat keluarga.

Sebanyak responden yang menggunakan alat kontrasepsi suntik dengan kategori lama yang menderita hipertensi sebanyak 13 orang $(38,2 \%)$ dan responden dengan kategori baru yang menderita hipertensi sebanyak 2 orang $(5,9 \%)$ dan responden yang tidak menderita hipertensi sebanyak 12 orang $(35,3 \%)$.

Hasil penelitian ini sejalan dengan penelitian Lestari (2013), yang menyatakan bahwa ibu yang lama menggunakan alat kontrasepsi hormonal suntik memiliki peluang 3 kali menderita hipertensi dibandingkan dengan ibu yang tidak lama menggunakan metode kontrasepsi hormonal suntik, sehingga ada hubungan yang signifikan antara lama penggunaan alat kontrasepsi hormonal suntik dengan kejadian penyakit hipertensi.

Metode kontrasepsi hormonal suntik dapat mempengaruhi tekanan darah, baik dengan kandungan estrogen maupun progesteron. Estrogen merupakan salah satu hormon yang dapat meningkatkan retensi elektrolit dalam ginjal, sehingga terjadi peningkatan reabsorsi natrium dan air yang menyebabkan hipervolemi kemudian curah 
jantung meningkat dan mengakibatkan peningkatan tekanan darah. Progesteron dapat merendahkan kadar HDL-kolesterol serta meningkatkan kadar LDL-kolesterol, sehingga terjadi arterosklerosis. Kadar LDLkolesterol tinggi dalam darah yang dapat menyebabkan penyempitan pembuluh darah dan retensi perifer pembuluh darah kemudian mengakibatkan peningkatan tekanan darah (Hartanto, 2010).

\section{KESIMPULAN}

Pada penelitian ini diperoleh kesimpulan bahwa terdapat hubungan yang bermakna antara lama pengunaan kontrasepsi jenis pil dan suntik dengan kejadian hipertensi pada wanita pasangan usia subur.

\section{REFERENSI}

Badan Koordinasi Keluarga Berencana Nasional (2005), Kebijakan dalam Kesehatan Reproduksi, Jakarta.

Hartanto, H. (2010). Keluarga Berencana dan Kontrasepsi. Cet.7. Jakarta: Pustaka Sinar Harapan.

Palmer, A. (2005). Tekanan Darah Tinggi. Jakarta : Erlangga.

Saifudin.(2005). Buku Panduan Praktis Pelayanan Kontrasepsi. Jakarta: Yayasan Sarwono Prawirohardjo.

BKKBN, (2011). Laporan Hasil Pelayanan Peserta KB Baru Menurut Metode Kontrasepsi Oktober 2011. [Online]. http://dashboard.bkkbn.go.id/BKKB NReports/Gabungan/Laporan\%20Bul anan/Tabel8A.aspx. Diakses 1 juli 2016.

DINKES.(2014). Indeks Pembangunan Kesehatan Masyarakat. Dinas Kesehatan Provinsi Sulawesi Barat. http://dinkessulbar.com/wpcontent/uploads/2014/11/BukuIndikator-Kesehatan-ProvinsiSulawesi-Barat-tahun-2013.pdf. Diakses 3 juli 2016.

Infodatin Pusat Data Dan Informasi Kementerian Kesehatan RI (2013). Hipertensi http://www.depkes.go.id/download.p hp?file=download/pusdatin/infodatin /infodatin-hipertensi.pdf. Diakses 30 juni 2016.

Kaunang,S.S. (2014).Hubungan Antara Penggunaan Kontrasepsi Pil Dengan Kejadian Hipertensi Pada Wanita Usia Subur Di Wilayah Kerja Puskesmas Bahu Kota Manado. Fakultas kesehatan masyarakat universitas sam ratulangi.http://fkm.unsrat.ac.id/wpcontent/uploads/2014/10/septyak.pdf. Diakses tanggal 5 juli 2016

Lestari, I.P. (2013). Hubungan Antara Lama Penggunaan Metode Kontrasepsi Hormonal Dengan Kejadian Hipertensi. Skripsi Program Studi Ilmu Keperawatan STIKES Telogorejo Semarang. 97.100/ejournal/index.php/ilmukeper awatan/article/viewFile/173/197. Diakses tanggal 1 juli 2016.

Pangaribuan, 1. (2013). Hubungan Penggunaan Kontrasepsi Pil Dengan Kejadian Hipertensi Pada Wanita Usia 15-49 Tahun Di Indonesia. Pusat tekhnologi intervensi kesehatan masyarakat.

http://ejournal.litbang.depkes.go.id/in dex.php/MPK/article/download/4233 /3961. Diakses tanggal 1 juli 2016

Tukiman, S. (2012). Hubungan Penggunaan Kontrasepsi Hormonal Dengan Kejadian Peningkatan Berat Badan Pada Wanita Pasangan Usia Subur Di Puskesmas Tamalanrea Makassar. Skripsi Program Studi Ilmu Kesehatan Masyarakat Universitas Hasanuddin. http://repository.unhas.ac.id:4001/dig ilib/files/disk1/115/--suryantitu5725-1-sampuld-n.pdf. Diakses tanggal 4 juli 2016 